BIBLID: 0015-1807, 48 (2021), 1 (pp. 37-62)

УДК 821.111-1.09Jejts V.B.:821.111-1.09 Eliot T.S. https://doi.org/10.18485/fpregled.2021.48.1.3

\author{
Милена Владић Јованов \\ Универзитет у Београду - Филолошки факултет \\ milena.vladicjovanov@live.fr
}

\title{
ИНТЕРТЕКСТУАЛНИ ДИЈАЛОГ ИЗМЕЪУ ПЕСАМА: JЕЈTСОВЕ РАЗГОВОР ИЗМЕЂУ МЕНЕ И ДУШЕ И ЕЛИОТОВИХ ПРВА И ДРУГА РАСПРАВА ИЗМЕЂУ ТЕЛА И ДУШЕ
}

\begin{abstract}
Апстракт: У раду је приказан интертекстуални приступ у проучавању две песме В. Б. Јејтса и Т. С. Елиота. Међутим, током анализе песама предочена је и поетика сваког песника посебно. У том односу приказан је појам дублетне поетике којим се обележава посебно Јејтсово стваралаштво, али у одређеним нијансама и Елиотов поетски систем. Дублетна поетика открива важну особину модернистичке поетике. Реч је о аутореференцијалности у којој стварност и референцијалност једне песме лежи у њеном дублету, а не у стварности, објективно или субјективно схваћеној. Савијање песама ка њима самима истовремено представља и извијање споља у приказивању стварности која окружује уметника, и посебно показује овим начином његовоу друштвену улогу. Он вите не пева о догађајима дана и свог времена већ пева о стварности коју види кроз претходна уметничка дела или кроз понављање својих у чијем се интертекстуалном простору обликује читаочево критичко мишьење. Читалаи је активан и пролази у песничком структурално-семантичком преплету у семиотичку и семантичку фазу. Такођ се отвара и питање метаквалитета јер песник показује начин сопственог стварања пишући о свом стваралачком искуству. Модернистички метаквалитет је сложен. Песника не видимо директно као у постмодернизму, већ он искуством стварања које описује предочава и начин стварања, отварајући своје дело динамичном читаочевом учешћу. Истовремено се у песничком искуству отварају критички промишьене бинарне опозииије које се доводе у питање а које су управљале хијерархијски и идеолошки читавом људском културом. Песници промииљају однос чулног и вечног, смрти и живота, пристуног и одсутног, спољашњег и унутрашњег, $и$ закључују да је увек реч о преплету датих појмова а не о њиховом искључивом избору.
\end{abstract}

Кључне речи: дублетна поетика, аутореференцијалност, метаквалитет, песничко искуство, структурално-семантички односи, семиотички и семантички читалаи, бинарне опозииије, поетски систем.

Abstract: This paper presents an intertextual approach to the study of two poems by W. B. Yeats and T. S. Eliot. In the analysis of the poems, however, the poetics of each poet is also presented separately. In this context, the concept of doublet poetics is presented, which characterizes especially Yeats's works, but also, in certain nuances, Eliot's poetic system. Doublet poetics shows an important feature of modernist poetics. It is about self-referentiality, in which the reality and referentiality of a poem lies in its duplicate and not in the reality which is understood objectively or subjectively. The 
simultaneous twisting of the poems into themselves represents the distortion of the exterior and the representation of the reality surrounding the artist, thus showing in particular his social role. He no longer writes about the "events of the day" and his contemporary time, but writes about the reality he sees through earlier works of art or through the repetition of his own, in whose intertextual space the critical opinion of the reader is formed. The reader is active and goes through both the semantic and the semiotic phase in the poetic-structural-semantic interweaving. The question of meta-quality also arises because the poet shows the way of his own creation by writing about his experience of creation. Modernist meta-quality is complex. We do not see the poet directly as in postmodernism, but through the experience of creation describing and showing the way of creation and he opens his work to the dynamic participation of the reader. At the same time, the poetic experience opens up critically thought-out binary opposites that are questioned and that have dominated the entire human culture hierarchically and ideologically. The poets rethink the relationship between the sensual and the eternal, death and life, the present and the absent, the outer and the inner, and come to the conclusion that it is always about the interweaving of predetermined concepts and not about their exclusive choice.

Keywords: doublet poetics, self-referentiality, meta-quality, poetic experience, structural-semantic relationships, semiotic and semantic reader, binary oppositions, poetic system.

У поетикама В. Б. Јејтса и Т. С. Елиота уочавају се поједине сличне особине. Једна од њих је оповргавање бинарних опозиција које нужно својом супротстављеношћу носе са собом хијерахизовани облик вредности. Песма је у делима Јејтса као барда посвећена друштвеној улози песника, али истоврмено није заборављена ни њена посвећеност теми стварања како саме песме тако и читавог песничког система и у њему пропитивања и критичког размишљања као посебног односа између дублетних песама које се ослањају једна на другу. У дублетној поетици остварује се особина аутореференцијалности јер се песме ослањају једна на другу а не нужно на стварност која их окружује. Јејтс постиже оба ефекта: песме јесу ослоњене једна на другу, али су теме често веома стварносне и односе се на политику и друштвена питања ирства. Развојни пут дублетне поетике односи се на промишљање различитих ставова. У почетку то су у Јејтсовој поетици коришћењем драмског начина personae које своје ставове износе веома једнострано. Такви поетски субјекти, ликови, преносе се из једне у другу песму и стварају таквим прелазом наративни процес у лирици. Реч је о „причи” о уметности. Прво је реч о причи као размени ставова која указује на немогућност искључивог избора. Јејтсова жеља је да нема искључивости у избору ставова. Тим поетичким начином постигао је да ликови, који као да играју на сцени и сцена им се мења из песме у песму, успоставе читав низ опозиција које више нису супротстављене већ остављају читаоцу, у простору који им је омогућен понављањем, да размисли о ставовима који често одређују уређење друштва. Један од ликова, поетских субјеката који се шета између песама, јесте и лик Луде Џејн. Навешћемо неколико наслова песама који то видљиво показују: Crazy Jane and the Bishop, Crazy Jane Reproved, Crazy Jane on the Day od Judgement, Crazy Jane and Jack the Journeyman, Crazy Jane on God, Crazy Jane Talks with the Bishop, Crazy Jane Grown Old Looks at the Dancers. 
Критички аспект можемо уочити у појединачним поетикама Јејтса и Елиота. Међутим, у овом раду проучаваћемо управо критички приступ који се отвара у простору између песама. Оно што прво уочавамо јесте да постоји неколико врста разговора. Неколико нивоа у разговорима. Јејтсова песма се паратекстуално ослања на Елиотову и обрнуто. Први вид интерпретације се отвара између два наслова који се понављају један у другом. Наслов Јејтсове песме гласи „Разговор између мене и душе” а Елиотових песмама „Прва расправа између тела и душе” и друге „Бахус и Аријадна, друга расправа између тела и душе”. Између наслова песама се отвара интертекстуални простор који нас упућује на тумачење које иде у једном правцу. Друго повезивање би било на тематском нивоу између топос тема тела и душе, које метафорично упућују на чулно и вечно. Неколико путева нам се отвара: један од њих је однос између саме песме и наслова, други између наслова песама различитих аутора, трећи између самих песама итд. Разговор између тела и душе је питање које се стално понавља. Само понављање није исто већ увек различито. Тема односа бинарне опозиције између коначности и бесконачности, чулног и пропадљивог и вечног и недодирљивог има посебан статус у модернистичкој поетици. Модернистички песници у различитим основама својих појединачних поетика постављају ово питање као питање смисла ${ }^{1}$ или потраге за смислом. Више није у питању истина, чак ни једна истина, већ да истине нема, и да постоје само различите и појединачне истине. Јејтс то питање поставља у оквиру песничке слике коју гради а која се ослања на природне и чињеничне елементе из његовог живота. Чињенице које су опипљиве и које својом чулношћу дају основу свету који је изван овог препознатљивог. Ствари које се могу дотаћи представљају основу онога што се не може дотаћи и достићи. У Јејтсовој песми „Разговор између мене и душе” појављује се „Сатоов древни мач”, према Сатоу који је посећивао Јејтсова предавања у Америци. Затим „Монтешиги”, ковач мача који је живео у Асафуми. Разговор се води између поетског субјекта и његове душе. Дат је као врста сценског разговора у коме душа има обличја бича и размишља о питањима постања и постојања људског живота.

Истовремено није реч о питањима и одговорима, већ о некој врсти монолога у коме се множе слике дана и слике живота, како појединачног тако и општег људског. Док душа зове свог „власника” да промисли о темама и поновљеним поетолошким проблемима Јејтсове поетике, а то је како разлучити једну од друге ствари, при чему се мисли или на уметност и уметничко стварање или на хијерархизовану поделу вредности која почиње од добра и зла, живота и смрти, вечног и чулног итд., поетски субјекат јој одговара описујући старе древне предмете као што је мач или знамења везана за људски живот. Основна подела која се у песми „Међу школском децом”

${ }^{1}$ Видети: Richard Poirier, Poetry and Pragmatism, Cambridge, MA, Harvard Univeristy Press, 1992. 
јавља у стиховима: „О цветни кестену дубокога жиља / Реци шта си: цвет, лист или пањ? / Тело понето музиком, очи пуне блеска: / Како разлучити плесача од плеса?, ${ }^{2}$ овде се јавља у стиховима које поставља душа: „Ко душу да разлучи од помрчине?”. ${ }^{3}$ Песнички субјекат одговора својој души о појединостима које чине људски живот али представљају истовремено и сјај и његову пролазност, с тим што се у пролазности која се везује за област чулног не проналази ништа лоше. Напротив, мач који је древан и стар, не дотиче рђа, већ његова кама хаљином дворске даме увијена, још увек сија али, што је још вредније, мач може бити још од помоћи. Душа човеку поставља питања везана за вечност али питања која захтевају избор, који би овде био на победничкој страни вечног, непроменљивог и јединственог. Међутим, човек јој одговара сликама из живота, реалним знамењима одбијајући да буде стављен пред избор. Он заправо наглашава нешто што је везано за Јејтсову дублетну поетику у целини.

Дублетну поетику у основи чини аутореференцијално ослањање једне песме на другу у којој референцијалност, стварност представља песма једна другој. Ауторефенцијалност није дата и представљена као нешто само по себи. Служи као поетолошко средство, између осталог, за изградњу песничких слика у којима се на иразит песнички начин поставља критичко питање и промишљање о избору вечног или чулног. Живота који се састоји од промена, младости, старости, осећања, патње, чулног крика али и слике ока, или сталних одрицања од онога што људски живот чини људским. Дублетна поетика се већ може уочити у Јејтсовој поетици у интертекстуалном простору између песама „Међу школском децом” и „Разговори између мене и душе”.

Јејтс је оваквим скоро хипертекстуалним постављањем песама у систем коме се може прићи разноликим, мултилинеарним путевима, а не само линеарним, које су вођене аксијалним структурама које почивају на почетку и крају, остварио многострукост читања и читаочевог стварања, „писања” као вида продубљеног, семиотичког читања у коме читалац „пише” и ствара дело, поштујући законе који су у поетском тексту већ успостављени али додајући тим законима своје нити у читању. Јејтс не бира избор, већ напротив сматра да избора нема, а ако се питање ослања на коначност избора и вредности које стоје иза избора, поручује да се чулно не може мимоићи, да је оно у основи вечног и преплетено је са њим. У једној од песама из збирке Одговорности под називом The Grey Rock, бесмртна вила Аиофа пита зашто су људи издали богове и определили се за смртни живот кад им она заљубљена у смртника може помоћи да остваре вечни живот. Она тада у очајању поставља питање: „Зашто наверније срце највише воли / Горку сласт лажних лица? / Зашто је вечна љубав она која пролази, / Зашто

${ }^{2}$ В. Б. Јејтс: Ја сам из земље Ирске: „Међу ђацима”, Београд, УИКЈ, 1999, стр. 67. Превод Милована Данојлића.

${ }^{3}$-Исто, стр. 70. 
људи боговима окрећу леђа?”. ${ }^{4}$ Одговор се може наћи у опису старости и младости у многим дублетним песмама. Као пример могу се навести „Путовање у Визант” и „Визант”, у којима су дате слике старости, њених недостатака, мана, али и врлина. Ако је стар човек, како песнички субјекат наводи у „Путовању у Визант”, „нико и ништа / дроњак на штапу”, 5 он има и врлину да му старост доноси искуство. Кад му се смртне хаљине скину са душе и она се вине пљеснувши рукама, онда се може скоро визионарски доживети уметничко дело представљено појединачно као мозаик у цркви, али се може доживети и описати и искуство стварања уметничког дела као што је птица, златна мајсторија, а онда са треће стране и утицај уметничког дела на публику, овде византску господу и госпође.

Другим речима, описали смо укратко да је са променама у људском животу везана и промена у уметничком стваралашту које је на крају ипак универзално и вечно. Другим речима, у смртним рукама човека крије се моћ стварања вечног. У основи вечног је у датим песничким сликама описано стварање које је обележено чулним и преплетом болних жеља тела, „помаме и глиби крвотока", 6 али у тој сложености налазе се „дуси рођени из крви” који „одбацују замешатељство, муку”, њ њих не може да додирне ни ватра рођена из ватре коју ништа не може да угаси али која ништа не може ни да запали ни уништи. Они прелазе у игру која представља стварање песничких слика које се умножавају у стварању дела, и у тој игри преплетено је чулно и вечно. Они јашу на леђима делфина од крви, што је чулно, али их зауставља мермерна дворана цара у којој су представљени као уметничко дело, као слика. Дакле, Јејтс не бира, већ представља сложеност живота, у овом случају у уметничком стварању. Преплетеност се огледа и у одбијању бинарне опозиције присуства/одсуства, која је предочена песничком сликом „смрт - у - животу - и - живот - у - смрти”8 и управо је присутно одсуство, оно што Јејтс назива натчовечним.

Слике дате у одбијању потребе избора могу се наћи и у представама и песничким сликама описа људског живота као острва. У поетици која одбија вечност и постављање питања избора, песнички субјекат супротставља увек одређену чињеницу из природе или људског живота са којом везује мисао о избору који је дат на промишљање. У песми „Инисфри, острво на језеру” у самом наслову наилазимо на име острва, као дела природе, али истовремено и људске потребе да отплови до тог острва које је у њему самом, односно да у себи самом пронађе мир, који симболично означава мир и хармонију

${ }^{4}$ W. B. Yeats: The Collected Poems of W. B. Yeats: "The Grey Rock", New York: Scribner Paperback Poetry, 1989, p. 106. Превела Милена Владић Јованов.

${ }^{5}$ В. Б. Јејтс: Ја сам из земље Ирске: „Путовање у Визант”, нав. дело, стр. 48.

${ }^{6}$ В. Б. Јејтс: Ја сам из земље Ирске: „Визант”, нав. дело, стр. 80.

${ }^{7}$ Исто, стр. стр. 81 .

${ }^{8}$ Исто, стр. стр. 80. 
између различитих људсих импулса који раздиру тело али и души задају муке. „Устаћу и отићи, отићи на Инисфри [...] / Имаћу оног мира што пада, кап по кап [...] / Устаћу и отићи, јер даноноћно, на жал / Пристиже талас, и пљуска, с маха на мах; / Свеједно стојим ли на стази, ил на плочнику, тај вал / Из дубине груди диже се, као дах." $"$ Представљена нам је сложеност Јејтсове слике која се даље чини све сложенијом што више повезујемо интертекстуалне просторе између ауторефенцијално повезаних песама, у којима дати простори често могу бити апоријски јер читалац стално и изнова тражи решење да изађе из простора, али га на том путу зауставља или му пут сече критичко промишљање које до модернизма није у толикој мери било заступљењо у поезији. Песнички субјекат је у овом пролазу себе представио погледом другог, погледом који га гледа, а да он себе не види већ осећа као острво, као део природе у којој ће саградити кућу, односно симбол своје душе, у којој ће пронаћи мир који капље као мед. Слике меда, веома брижљиво описане и упечатљиво дате, повезане су са миром као апстрактном, мисаоном именицом али и стањем у коме се проналази хармонични пут натчовечног.

У овим интерпретативним путовањима читаоцу помажу стихови - трагови које песник поставља као назнаке на путу које читалац проналази, али не увек све, и не увек стално. Што више чита, више их проналази и обогаћује разумевање и тумачење поезије које је често у додиру са стварањем песме. Стихови који постављају бинарне опозиције смрти и живота, играча и игре, замешатељства, односно преплета чулног и вечног у стварању уметничког дела и изграђивања вечног, у песми о Инисфрију представљени су питањем али и истовременим закључком да је свеједно где појединац стоји, на плочнику или стази, јер је вал који се диже из језера вал који се диже из груди као дах. Дакле, све је повезано и идентитет песничког субјекта је истовремено приказан и кроз борбу у поетском субјекту, али и сликама природе која је снагом имагинације и имагом продрла у стварање идентитета и појединачног човека и човечанства уопште.

У Елиотовим песмама могу се такође пронаћи песничке слике у којима се слично воде представљања сукобљеног вечног и чулног али и принцип источњачке мудрости према коме све што је створено мора бити поништено, другим речима, ништа није вечно већ су око нас и у нама самима конструкције које градимо да бисмо их поново разрушили са новим сазнањима. Примера ради, у песми „љубавни јади Џ. Алфреда Пруфрока” сусрећемо се са сликом израженом необичним језичким спојем. „Требало је да сам пар крњих штипаљки / Тихим морима што стружу по днима”. ${ }^{10}$ Овај стих проучаваоци Елиотовог поетског система тумаче на различите начине. Аутор

${ }^{9}$ В. Б. Јејтс: Ја сам из земље Ирске: „Инисфри, оствро на језеру”, нав. дело, стр. 7.

${ }^{10}$ Т. С. Елиот: Песме: ,Љубавна песма Џ. Алфреда Пруфрока”, Београд, СКЗ, 1998, стр. 7. Превод Ивана В. Лалића. 
Вилијам Џ. Остин (William J. Austin) наводи да су клешта део целине и да је стога Пруфрок одвојен од свог бића, да је дат у партикуларијама, као што је слика где је прибоден иглом и плази се са зида, да је формулисан као фраза, и како онда да изрази „остатке дана”. Он је живот на кашичице измерио и обучен је опет у деловима, предочена је његова крагна и кравата. За Остина су стихови: „Гледао сам дим што диже се из лула / самотних људи у кошуљама” такође партикуларија слична стиху „Тихим морима што стружу по днима”. ${ }^{11}$ Остин истиче да „потрага за јединством и жеља за целином, може захтевати поништавање селфа, остављајући примитивне структуре да стружу по дну тихих мора. [...] Део Пруфрокове личности жели да среди свој свет према сопственој жељи, и чинећи то да избрише било какве или све разлике/неспоразуме који се могу појавити између аспеката његове персоналности, на исти начин као што се могу појавити препреке између онога што он и ,јединство', саговорник коме отвара своју личност, могу мислити о његовим деловањима”. ${ }^{12}$ Остин наставља да Пруфрок заправо сумња у „идеално” које је за њега недодирљиво. Грубо је одбијен од онога што жели, те му се свет дели на низ појединости, детаља, фрагмената, делова тела. Аутор сматра да нам Пруфрок поручује да се он идентификовао, да он јесте оно што су његови делови, знаци и површински детаљи. Међутим, Остин закључује: да би Пруфрок ,постигао идентитет, он мора да прихвати разлике и стога избегне потрагу за епифанијом". ${ }^{13}$ Не може се бити само нешто, већ то нешто мора имати и значење, наставља Остин према трагу из Елиотове докторске дисертације, напомињући да је „Пруфрокова жеља само наизглед жеља са самоприсутним јединством жеља и акције, јер једноставност ,крњих штипаљки' не упућује ништа мање на суштинско одсуство, како у свету тако и у њему самом." 14

Уколико посматрамо управо превод са енглеског „крњих штипаљки” и упоредимо га са оригиналом “ragged claws", можемо у складу за значењем појединих делова песме и Пруфрокове потребе за промишљањем вредности из читаве културе, предочити и други превод. Наиме, „оштре канџе”. Пруфрок није представљен како га већина критичара види као несигуран и немоћан, као расцепљен и одвојен од света и себе. Напротив, ако бисмо погледали стих у новом преводу, он би означавао, према теорији динамичке психијатрије, да Пруфрок оштрим канџама гребе дна тихих мора. Другим речима, море би било симбол непознатог, док би канџе представљале потребу да се за тим непознатим, ако хоћемо несвесним, трага и дође до другачијих сазнања. Пруфорк има значење и добро зна где је његово место у свету, али

\section{${ }^{11}$ Исто}

${ }^{12}$ William J. Austin: A Deconstruction of T. S. Eliot, The Fire and The Rose, New York, The Edwin Mellen Press, 1996, p. 130.

${ }^{13}$ Исто, стр. 133.

${ }^{14}$ Исто. 
промишљајући о Хамлету поручује нам да управо зна за питање границе овог и оног света, и наводи да он није Хамлет који у чувеном монологу „бити или не бити" наводи да људи пре прихватају муке овог света јер са оног се нико вратио није. Пруфроков песнички субјекат не каже само то, већ и да он уопште није требало да буде Хамлет. У енглеском оригиналу увиђамо да је то управо значење за које Остин верује да недостаје Пруфроку. „№! I am not Prince Hamlet, nor was meant to be". ${ }^{15}$ Пажљивим читањем уочићемо енглеску језичку формулацију, „nor was meant to be”, у којој се појављују глагол „to be” и „mean / meaning”, другим речима: није требало да значим ништа у садашњости у присутном. Значење које имам јесте оно које је у кретању разлика, у деконструкционистичком differance, и мој идентитет је увек у садашњости која је модификација прошлости и будућности, посебно када су у питању жеље које ће бити остварене.

Слично је и са пажљивим читањем које се везује за „крње штипаљке”, односно за „оштре канџе”. Требало је да сам пар крњих штипаљки, али нисам. Другим речима, нисам сада, нисам то учинио и могу да промишљам о свему. „I should have been a pair of ragged claws / Scuttling across the floors of silent seas". Конструкција на енглеском нас упућује да је нешто требало, али се није десило. Негација се не види у српском преводу јер је у језичкој конструкцији на енглеском већ садржано значење. Пруфрок је трагалац, никако неко ко је несигуран. Поготово што испитује управо границе чулног и вечног, испитујући њихове утицаје из претходних дела и епоха и вредности које уметничка дела носе са собом и преносе другима.

У „Квартетима” сусрећемо се са још једним симболом воде. Реч је о реци. Река је симбол човекове унутрашње променљивости у којој спољашње, стално у облику утицаја, културне интројекције, улази у нешто спољашње али не разара унутрашње, већ га чини целовитијим и значајнијим, смисленијим и смисаонијим, својим продором и крајњим преплетом спољашњег и унутрашњег. Као што вечно не би могло без чулног у Јејтсовој поетици, у Елиотовој поетици снажно је изражена бинарна опозиција спољашњег и унутрашњег, у коме је за услов постојања унутрашњег неопходно имати управо спољашње: „Не знам много о боговима; но мислим да је река / Снажан смеђ бог - мргодан, неукроћен и упоран [...] становници градова / скоро да забораве смеђег бога - али он, стално непомирљив, / Држи се својих доба и јарости, разоритељ, опомиње / На оно што људи рађе заборављају. [...] Његов ритам беше присутан у дечјој соби, / У бујном ајанту у априлској башти пред кућом / У мирису грожђа на јесењем столу / И вечерњем кругу зимске плинске лампе". ${ }^{16}$ Оно што примећујемо јесте да песнички субјекат

${ }^{15}$ T. S. Eliot: The Complete Poems and Plays 1909-1950: "The Love Song of J. Alfred Prufrock", New York: Harcourt Brace and Company, 1952, p. 7.

${ }^{16}$ Т. С. Елиот: Песме: „Четири квартета, ДС”, Београд, СК3, 1998, стр. 162. Превод Ивана В. Лалића. 
у Елиотовој поетици посматра нешто слично што ради и песнички субјекат код Јејтса. Иако је река, неукротиви, смеђи бог у нама, њен ритам је исто тако присутан у дечијој соби, у башти, мирису грожђа, светлости зимске, плинске лампе. Другим речима, у Јејтсовој поетици детаљи су изражени као представа историје чулног, променљивог живота у појединостима којима се човек служио као што је мач у рату или кућа на острву, или људи који су живели у одређено доба и бавили се занатом који је данас непотребан или превазиђен, као ковачи. Код Елиота их видимо у призору дечије собе, мириса грожђа, јесењег стола, светлости лампе. Дакле, ритам реке која је унутрашњост али истовремено и спољашњост као део који припада природи, има ритам у свим детаљима људског живота.

Живот са свим појединостима и у њима читавим богатством, који чини овај смртни живот. Живот у појединости одговор је у Јејтсовој песми „Разговор између мене и душе”. Он се наставља у детаљима који се односе на људски живот који је променљив. „Издржи муку растења, страшну; / Издржи срамоту детињства; безнађе / Дечака који постаје човек млад [...]. Па чему сва та бекства, када / Слава са зимским ветром долази? / Спреман сам: нек све још једном буде, / Чак и ако је живот скок наглавце / У јарак, међ слепе пуноглавце [...]. Лудост што човек је чини ил сноси / Онда кад горду жену проси, / А она му није по души сродна". ${ }^{17}$ Оно што душа пита песничког субјекта, селф другим речима, јесте: зашто се замарати имагинацијом која мори око и душу? Зашто призивати слике имагинације чак и кад човек остари и мислити на сва знамења живота, љубави и рата. Душа позива селф да презре машту, хтење, жеље, изазове, те се чини да у овим стиховима као да одјекују стихови Пруфрока који се пита да ли су жеље оно што жели, да ли је активност некад потребна кад се мисли не могу изразити јасно, а опет такав је језик, поручује песнички субјекат из Елиотових „Квартета”. Реч се ломи и пуца под напоном да би изразила смисао. Предачка ноћ би могла, како наводи ,душа”, ако се све напусти, „да те реши злочина што се зове / Једанпут смрт а други пут рођење". ${ }^{18}$

У једном тренутку селф је одвојен од душе, личост од себе, и успоставља се напоредна линија ,jа - моја душа" или на енглеском my self - my soul. Ова раздвојеност упућује на критичко промишљање и субјекта, појединца, личности, и душе као слике нечег што превазилази чулност и смртност. Међутим, на крају долази до спајања, до хармоније и то управо у овом свету. Јејтс то постиже употребом сложене песничке слике која се појављује са метаквалитетом, карактеристиком која нам указује на појаву песника. Песник Јејтс говори о себи али скривено у облику сложеног и слојевитог модернистичког метаквалитета. Кроз уметност решава се питање раздвојености душе и селфа, односно вечно не побија чулно већ долази до песничких слика у

${ }^{17}$ В. Б. Јејтс: Ја сам из земъе Ирске: „Разговор између мене и душе”, нав. дело, стр. 71-72.

${ }^{18}$ Исто, стр. 70. 
којима су питања спојена и стопљена. Постоји место на коме су све акције спојене и измерене мислима, и представљају управо ону врсту хармоније и идентитета коме тежи Пруфрок када поставља питања о различитим људским одлукама уоченим у делима из свеколике књижевности и културе. Песник се код Јејтса појављује у слици у којој говори о себи, у стиховима у којима се обраћа себи али и нама читаоцима речима: „Кад човек, као ја, одбаци грижу / Груди му милост испуни жива, / Што гони на песму, на кликтаје, / Тад свака ствар нам благосов даје, / И све што погледамо блажено бива", ${ }^{19}$ или у енглеском оригиналу: „When such as I cast out remorse / So great a sweetness flows into the breast / We must laugh and we must sing, / We are blest by everything, / Everything we look upon is blest". ${ }^{20}$

Компаративним, интертекстуалним отварањем простора и читаочевим увидом у интерпретацију коју ствара у пролазима између песама, можемо уочити да је песма, песничко дело као и искуство песника као човека и ствараоца, оно које може спојити слике чулности и вечности. Компаративан увид је пред нама већ са песмама „Путовање у Визант” и „Визант” у којима песник дочарава да је уметност света земља у коју се одлази и из које се долази. Метаквалитет путем кога можемо уочити песника у „Квартетима” говори нам да је песничко средство, а то је језик, једно од најмоћнијих али и најнемоћнијих средстава јер како песник, кога можемо готово постмодернистички да видимо како седи за столом „после двадесет година углавном проћерданих, [...] настојања”, може да научи „употребу речи” кад је сваки покушај „потпуно нов почетак, и друга врста неуспеха / Јер човек научи само да боље искористи речи / Да изрази оно што више не мора да каже, или начин / На који више то не жели казати. И тако сваки подухват / Јесте нови почетак, препад на неартикулисано / Са јадном опремом што све гора бива". ${ }^{21}$

Елиот је у односу чулног и вечног, односно у стварању уметничког дела више окренут самом језику, проблемима како створити и изразити стварност, док је за Јејтса питање вечности и светог заправо питање уметности. То се може уочити и на самом језичком плану. Иако и једног и другог песника видимо у метапоетском тексту, за Јејтса можемо рећи да слике које нам том приликом о себи предочава нису те врсте сложености која се јавља у Елиотовој поетици окренутој проблемима језичких нивоа свих кулутра. Његови метаквалитети јесу донекле и посмодернистички, јер поставља питање шта би дати појам изражен на одређени начин представљао у његовом савременом добу. Светост и питања хришћанске цивилизације у Јејтсовој песми могу се уочити не само као дублетна поетика јер је свети град свет стога што је уметнички, већ и на језичком плану који је лако уочити. Појављују се речи

\footnotetext{
${ }^{19}$ Исто, стр. 7.

${ }^{20}$ W. B. Yeats: The Collected Poems of W. B. Yeats: “A Dialogue of Self and Soul”, нав. дело, стр. 236. Превод Милене Владић Јованов.

${ }^{21}$ Т. С. Елиот: Песме: „Четири квартета, ИС”, нав. дело, стр. 160. Превод Ивана В. Лалића.
} 
и појмови који на то упућују, као што је: небо, грешник, опроштај, грижа, кајање, благослов, блажено. Морамо се у том светом јединству смејати и певати, и тада све нам благослов даје и све благосиљамо сами. Елиотова расправа између тела и душе има два дела. Прва и друга дебата, с тим што друга дебата има и алузивни ниво који нас одводи до посебног односа модернизма према традицији који ће у постмодернизму бити још наглашенији у виду веће границе између постмодерног и традиционалног. Наиме реч је о Бахусу и Аријадни. Ову врсту традиције Јејтс не постиже научним нивоом, већ помињањем појединости из живота, имена људи из његове савремености или уопштеног става о богатству Византа. Елиот има другачији став. На њега је донекле утицао и Езра Паунд који је Елиоту прецртао епиграф за „Пусту земљу” преузет из дела Џозефа Конрада „Срце таме” и уместо њега упутио Елиота да изабере учевнији епиграф, наиме из антике. Реч је о цитату који Елиот преузима из Петронијевог „Сатирикона” и чувене приче о Сибили из Куме која је заборавила да уз вечност од Аполона тражи и младост те се претворила у прах и једина жеља јој је била да умре. Насупрот овој врсти вечне антике јавља се непомирљиво животни лик Курта из „Срца таме”, који у последњим тренуцима смрти, угледавши је и осетивши је, може да каже само „ужас!” заборављајући на толике смрти које је погледом наређивао.

Смена ова два епиграфа које можемо уочити у факсимилу „Пусте земље” упућује и на интертекстуално проучавање саме „Пусте земље” у простору између два епиграфа, али и на Елиотову поетичку праксу у целини. У Елиотовој „,Пустој земљи” јавља се монолитан, лирски глас обележен и изражен метафором, и метонимијски, наративни гласови, због којих „Пуста земља” није пуста, већ је пренасељена. Погледајмо како се ове линије преплићу у песмама расправа о души и телу. Прво што морамо нагласити јесте да су то ране Елиотове песме написане у периоду од 1909. до 1915. године, у време када није издата ни званична верзија збирке „Пруфрока и његових запажања". Дакле, ове песме могу се тумачити као основа каснијим песмама које су званично издате. Ништа мање и ништа више се ране песме не тумаче а да нису у вези са каснијим Елиотовим радовима. Прва и друга расправа између тела и душе интертекстуално су повезане саме по себи, затим су повезане са читавим Елиотовим песничким стваралаштвом. А онда тек компаративно са Јејтсовом песмом о дијалогу селфа и душе. Колико је ту преплета, колико утицаја, утврдићемо пажљивим ишчитавањем Елиотових песама.

Оно што у првом кораку можемо да уочимо јесте да је Елиот започео тему о вечном и чулном као бинарној опозицији коју је у овом првом маху представио као раздвојену. Касније је Елиот, склон песничкој поетици модернизма, предочио песничке слике у којима је чулност представљена као део културе а вечност као несхватљиви појам. Међутим, Елитова поетика и саме песме већ у раном периоду представљају назнаке онога што ће Елиот касније званично објавити као своје песме. Ране песме представљају једну 
врсту подструктуре која се касније појавила као главна структура. Без раних песама, данас се нико на Западу не усуђује ни да тумачи каснија дела. Реч је наиме о понављању стихова трагова али и тематских целина које функционишу касније у изградњи песничких слика.

Погледајмо како су стихови ове две песме расправе подељени на рефрене и саме строфе. „Слепи старац што кашље и пљује / Тетура се по улицима и сливницима". ${ }^{22}$ Сливници и улице неминовно читаоца увлаче у простор тумачења и повезивање са раним градским песмама као што су „Први и Други капричо у Северном Кембриџу” и „Четврти на Монпарнасу”. Послушајмо и осетимо само те стихове чији контекст не само да је у овим Елиотовим песмама расправе, већ се и уградио као неизбежни део песничке слике коју читалац не би могао да протумачи да не познаје рану Елиотову поезију. Улице и сливници, језички топос јесу: „Уличне оргуље, бучне и крхке [...] Флаше и разбијено стакло, / Изгажено блато и трава [...] и гомила дроњавих врабаца / кљуца по сливнику са одвратном стрпљивошћу”. 23 Зауставимо се код стиха који упућује на „стрпљивост”: „Старачком стрпљивошћу / Испитује / Увело лишће / Наших осећаја". ${ }^{24}$ Природа, сада само градског типа, спојила се са великом темом Елиотове поетске мисли, интроспекцијом и промишљањем о себи у потрази за сопственим идентитетом.

Можда нам на први поглед изгледа да је слично са Јејтсовом природом, али није. Елиотова природа је везана за град, онакав каквог га данас не можемо замислити, али га у деловима и парчићима чекања на аутобуским станицама памтимо. Повезаност песама у којима је контекст већ у тексту, не само да нам је омогућила другачије читање већ и виђење наше сопствене стварности. Поетски текст се слио и савио аутореференцијално са самим собом не само да би изразио сопствени поетски систем и показао да га као систем једино можемо и разумети, већ је изразио не само тадашњу реалност, и то чулну и свакодневну, са нашом у којој на аутобуским станицама, као на станицама метроа у великим градовима, стојимо као окисле црне гране, као утваре које збијене као гране не разговарају једне са другима, што је очигледни утицај Паундове песме „На станици подземне железнице”. У двостиху Паундове песме јавља се управо дух града као визија песника о градском животу и појединост која се везује као имаго за начин живота. Истовремено ова слика паундовске имажистичке поетике представља и визију и стварност. Навешћемо овај чувени двостих Паундове песме: „Нагли налети тих груписаних лица / Латице на окислој, црној грани.”25 У овом

${ }^{22}$ T. S. Eliot: Inventions of the March Hare, Poems 1909-1917: "First Debate between the Body and Soul”, New York, Harcourt Brace and Company, 1996, pp. 64-65. Превела Милена Владић Јованов.

${ }^{23}$ Исто, p. 13.

${ }^{24}$ Исто, pp. 64-65.

${ }^{25}$ Езра Паунд: Песме: „На станици подземне железнице”, Београд, БИГЗ, 1975, стр. 87. Превод Милована Данојлића. 
имагу, кратком двостиху престављена је двострука поетика коју уочавамо и код Јејтса и код Елиота. Паунд је неколико година радио као Јејтсов секретар и у то време које бележи студија ${ }^{26}$ утицао је да Јејтс пређе на краћи стих и да му синтакса буде једноставнија. То ће до краја остати обележје Јејтсове поетике. Истовремено, Паунд је скраћивао Елиотове стихове, што можемо уочити у факсимилу ${ }^{27}$ „Пусте земље”, и то су можда највећи утицаји које је Паунд као модератор модернистичке поетике остварио. Рецимо, Џ. Џојс није дао ни да му се у прози један ред промени. Х. Д. (Хилда Дулитл), коју је Паунд називао својом малом вилом, још је и допуштала критичареве промене, што би данас било незамисливо. Паунд представља естетику романтизма у малом, дакле визију нечег непојмљивог кроз слику нечег што је сасвим чулно и стварносно, јер је реч о људима на станици метроа, који груписани ипак не разговарају једни са другима и путујући у групама не познају једни друге чак и кад им затреба каква помоћ. То чини у облику песничке слике која је заједничка и Елиоту и Јејтсу.

Међутим, ако се вратимо Елиоту и интертекстуално повезаним песмама о расправама о души и телу, сусрешћемо се са сложеним обликом постављања питања које више не чини поетски субјекат као код Јејтса већ са разговором који се води унутар себе и истовремено ван себе. Бинарна опозиција између чулног и вечног не само да је доведена у питање, већ је оборена у самом разговору јер је поетски субјекат за разлику од Јејтсове песме води у себи као врсту интроспекције, спознања себе али и читаве културе која полаже право на појаве које припадају избору. Елиот у овом супротстављању мисли према животу заузима сложен и на први поглед неразумљив начин у схватању. Песнички субјекат пропитује себе и нема директног разговора као у дублетној поетици Јејтса, између поетског субјекта, селфа и његове душе већ песнички субјекат описује себе кроз слику коју има о себи а коју је изградио путем вредности које су устаљене у читавој европској култури. Но, ни то није крај. Елиотов поетски субјекат успоставља интертекстуалну иронију и према себи и према друштву, постојећем и прошлом, остављајући поруку друштву које ће тек доћи. То чини сложеним путем понављања стихова трагова који уносе читав контекст како Елиотових песама тако и претходних уметника. Читаоцу је на вољу да ли ће повезати песму кроз рефрене и створити ново дело или ће у некој врсти наративног агона супротставити значење рефрена са стиховима строфа који им претходе. Погледајмо како би читалац спојио рефрене и онда их применио у другој линији интерпретације.

\footnotetext{
${ }^{26}$ Видети: James Longebach: Stone Cottage, Pound, Yeats, and Modernism (Oxford, Oxford University Press, 1988).

${ }^{27}$ Видети: Т. S. Eliot: The Waste Land, A Fascimile and Transcript of the original Drafts Including the Annotations of Ezra Pound (New York, A Harvest Book, Harcourt, Inc., 1971).
} 


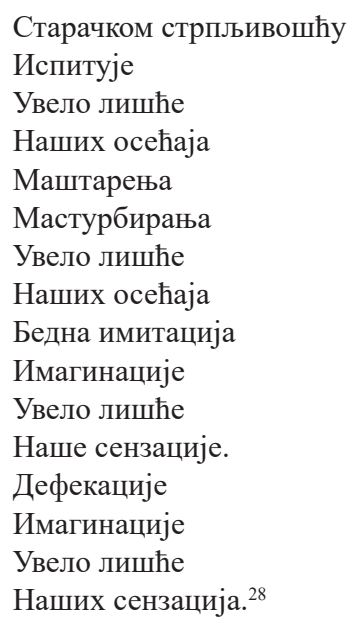

Елиотова поетика дозвољава читаоцу да прави сопствени систем писања, тако да спојени рефрени могу означавати песму, односно писање које је извршио читалац. У строфама се налазе промишљања о питањима и одговорима о идентитету који се односи на структурни однос вечног и чулног, који у својим поструктуралним појмовним нијансама имају своје пуно значење. Старац који стрпљиво испитује долази до испразности чисте идеје, „док уличне оргуље кроз прашњаво дрвеће / Понављају: Искористи оно што ти је дато - [...] између поетског субјекта Успавани мозак не реагује [...] / Нити чисти / Нагомилани талог чињеница. / Видљиви муљ физичких осећаја / Космичка мрља џиновског палца / На исписаном рачуну за душу. / А кроз дрвеће се непрекидно чује / Раштимовани звук / Уличних оргуља. [...] Апсолут! Потпуни идеалиста / Племенити дивљак / (Замисао најнепријатнија) / Племенити дивљак на неугледном углу / Води ме ка чистој идеји - / Посматрањем природе без љубави или страха / На трен / Не одустајемо - / Све док се живот не претвори у осмех / Једноставан и мудар. / Уличне оргуље кроз дрвеће / Завијају и шкрипе". ${ }^{29}$ Прво отварање контекста и унутрашњих простора уочавамо у самој песми. Реч је о деконструкционистичком понављању које је „исто” а различито, у том смислу што се уводе из резервоара значења нове нијансе.

Прво понављање у оквиру саме песме јесте стих траг „уличних оргуља”. Међутим, оне се не појављују само у овој песми, већ и у другим званично издатим песмама, односно онима које припадају објављеним збиркама, за разлику од Бележнице песмама која није била објављена за време Елиотовог

${ }^{28}$ T. S. Eliot: Inventions of the March Hare, Poems 1909-1917: "First Debate between the Body and Soul”, нав. дело, стр. 64-65. Превод Милене Владић Јованов.

${ }^{29}$ Исто. 
живота и коју је приредио Кристофер Рикс, а у којој се налазе управо песме о расправи између тела и душе. Бележница није нацрт песмама, већ збирка која је касније откривена у заоставштини Џона Квина, Елиотовог пријатеља, мецене и адвоката. Бројне студије на западу више не познају само проучавање Елиотових „званичних” песама већ је оно укључено у свако проучавање поређења са раним песмама од 1909-1917. ,„Уличне оргуље” или вергл одводе нас до званично издате песме „Портрет једне госпође”. ,Чувам своје спокојство, / Владам својим стањем, / Осим када вергл маханички, уморно буди, / Понавља неку отрцану арију / С мирисом зумбула што из врта веје, / Подсећа на оно што други су жудели људи. / Јесу ли тачне или погрешне ове идеје?”зо У „Првом разговору између тела и душе” успоставља се однос између чулног и вечног у људском животу, с тим што је чулно дато више у градским сликама, али све заједно реч је о интроспекцији, спознаји себе и откривању сопственог идентитета који је увек у разликама и њиховом кретању. Промишљање какви су поступци чулног и какво је вечно дато је у „Портрету једне госпође” у стиху „Да ли су тачне или погрешне ове идеје”.

Успоставља се двоструки пролаз: један је између песме „Портрет једне госпође” и „Првог разговора између тела и душе”, други је дат опет на две шине, чиме се пролази само удвостручавају и умножавају. Реч је о пролазима који се налазе унутар самих песама, како раних тако и ових званичних. Интроспекција је приказана у стиховима који почињу идејом да песнички субјекат влада својим стањем, осим када вергл понавља неку отрцану арију с мирисом зумбула што из врта веје и која подсећа на оно за чим су жудели други људи. Овај стих нас одводи до „Пусте земље” и сцене о двоје младих који су у врту зумбула и њихове љубави али и до чувене љубави Тристана и Изолде и стихова из Вагнерове опере. Сви ови апоријски путеви које читалац ипак решава пажљивим ишчитавањем упућују нас да је реч, не само о повезаним песмама, или збирци песама са одређеним распоредом који утиче на значење и тумачење песама, него и о поетском систему у коме распоред прави сам читалац, који повезује стихове трагове. Додуше, као што смо и навели, аутор му оставља назнаке на тим бескрајним путевима тумачења. У питању је љубав, која је неиспуњена у „Портрету једне госпође”, љубав која практично остаје без комуникације, у којој свака страна и млади годподин и гопођа као да причају приче сами за себе иако се обраћају једно другом. Вергл свира арију која подсећа на врт са зумбулима, а ту је господин без речи, „загледан у срце светлости, тишину". ${ }^{31}$ Гледано са тематске линије, тема љубави повезана је двоструко и са интроспекцијом и са питањем чулног и вечног, али и са љубављу, која нам се у интерпретативном пролазу између „Портрета једне госпође” и

${ }^{30}$ Т. С. Елиот: Песме: „Портрет једне госпође”, нав. дело, стр. 12-13. Превод Ивана В. Лалића.

${ }^{31}$ Т. С. Елиот: Песме: „Пуста земља”, нав. дело, стр. 54. Превод Јована Христића. 
„Пусте земље” указује поређењем класичне музике са обичним, уличним звуком вергла. Када љубав постане јефтина арија, онда је тешко утврдити када је почела, а када нестала.

Слично у „Првој посланици Коринћанима”, апостол Павле поручује Коринћанима да, када нема љубави, може се остварити много шта, али ће срце звучати као празна меденица, као празан лим. Слично је и у интертекстуалном поређењу филма „Три боје” Кишловског, који је уз дате речи о љубави у филму предочио и лик композитора који ствара музичку композицију која прати и одговара датим стиховима. Интересантно је да је у делу „Плаво” овог филма, реч не само о љубави, већ и о слободи, те ако нема љубави, нема суштински ни слободе. Погледајмо како то звучи у Библији. „Ако језике човечије и анђелске говорим а љубави немам, онда сам као звоно које звони, или прапорац који звечи. И ако имам пророштво и знам све тајне и сва знања, и ако имам сву вјеру, да и горе премјештам, а љубави немам, ништа сам."32 Љубави ће бити, како наводи апостол Павле, чак и ако престане пророштво, ако умукну језици, и ако разума нестане. У другој песми која има призвук као и „Пуста земља” према антици, тачније грчкој митологији, јер је реч о Дионису и Аријадни, које познајемо из грчких митова, говори се поново о телу и души. Преплет је дат у облику и лику Диониса који би представљао тело, чулност, али и изнова рађање Аријадне, која је према једном виђењу мита била чак и његова жена. Минојева кћер, Аријадна коју прате многе митемске приче, добила је од Диониса Хефестову круну, али је изгубила живот у Дионисовом сукобу са Персејем. Да би казнио Аргивце, Дионис је њиховим женама помутио разум и оне су у лудилу убијале и растрзале своју децу.

Међутим, ово је само једна од линија и требало би је гледати као антички ниво, који се преплиће са семантичким нивоом или боље рећи нивоима саме песме. У првом делу може се рећи да поетски субјекат прича о Дионису и Аријадни, али исто тако може се рећи да је реч о једној обичној љубави, двоје људи. „Видео сам да им се живот попут таласа / Уздиже и разбија. И никад се не разбије - / А могао је да се преломи преко хумке / Непознатих намера и неизговорених питања." 33 Први део је прича о љубави или односу између двоје, док стих о неизговореним питањима припада структурално-семантичком преплету интроспекције и проналажења идентитета који се налази у разбијању не само бинарне опозиције чулно-вечно већ и других хијерархизованих опозиција које воде ка идеолошким представама које су увек на рубу избора а тиме и ограничења. Стварни свет се преплео са нат-

\footnotetext{
${ }^{32}$ Свето писмо: „Коринћанима посланица прва апостола светога Павла, глава 13, 1, 2, Београд, ЈБД, 2003, стр. 152. Превод Вука Стефановића Караџића.

${ }^{33}$ T. S. Eliot: Inventions of the March Hare, Poems 1909-1917: "Bacchus and Ariadne, 2nd Debate between the Body and Soul”, нав. дело, стр. 68. Превод Милене Владић Јованов.
} 
природним, као што стихови поручују у времену: „А ја сам видео како се још једном Време / Споро урезује на огрубело лице.” ${ }^{\prime 4}$

Видети време је поетска метафора о којој би се могао написати засебан текст. А оно се овде показало једино како је и могуће, а то је у чулном времену. О времену које је вечно Елиот говори у „Квартетима” када у необичним језичким обртима наводи да је време које је вечно непостојеће јер се не може искупити. Односно да то време није вечно присутно. Присутност и вечност не иду руку под руку као што се дуго времена сматрало у западној метафизици. „Ако је читаво време вечно присутно / Читавом времену нема искупљења. / [...] Кораци одјекују сећањем / Низ ходник којим нисмо кренули / Ка вратима што их никад не отворисмо / У врт ружа. / Моје речи одјекују / Тако, у твом духу." ${ }^{35}$ Не само да време не може бити вечно присутно, већ је са њим повезан и глас који се као најмање видљив материјални означитељ често користио као подлога присутности ума, логоса, вечне истине итд., већ је са њим повезан и одјек, који опет мора имати сопствену референцу, док овде одјек нема никакву референцу, дакле понављање и траг пре порекла. Чулно пре вечног. Како би могао да одјекне глас у нечијем духу ако није изговорен или да се чује ходником којим нико није кренуо? Питања идентитета и самоиспитивање у Елиотовој поетици распршило се и умрежило у читав Елиотов поетски систем: од ране до касне поезије.

Такође је важно приметити још један облик који је повезан са скоро свим питањима у Елиотовој поетици. Реч је о преображају, топос теми светске књижевности још од Овидијевих „Метаморфоза”. Као што се Дионис преображавао, нестајао и поново настајао, тако се и чулно преплитало са вечним у Елиотовим поетским сликама. Поновни почеци и крајеви и крајеви који су почеци, али једино тако што су у њима преплетени трагови почетака и претходних крајева. „Али коначно почети, безазлено и чисто / Изненађено, али свесно - то је тријумф који не смеш да приуштиш! / Да не ослободи невиност што обавија / Тиху поноћ његове чауре. / И док га земља храни / Он лежи у својој ћелији и сања своја крила." ${ }^{\prime 6}$ Преображај се у Елиотовој поетици уочава у сложеним песничким сликама које такође у себи спајају античку раван са структурално-семантичком равни саме песме. Рецимо, у „Пустој земљи” сложеност метаквалитета као и аутореференцијалности огледа се у песничкој слици о Филомели. Она је представљена стиховима траговима чијим спајањем долазимо као читаоци до приче о Филомели а тиме не само до сложености песничке слике, већ и до наративности у поезији. У другом, трећем и петом делу „Пусте земље” говори се о Филомели али и о песнику који пева о њој. То више није само Овидије који се помиње

\footnotetext{
${ }^{34}$ Исто.

${ }^{35}$ Т. С. Елиот: Песме: „Четири квартета, БН”, нав. дело, стр. 147. Превод Ивана В. Лалића.

${ }^{36}$ T. S. Eliot: Inventions of the March Hare, Poems 1909-1917: "Bacchus and Ariadne, 2nd Debate between the Body and Soul”, нав. дело, стр. 68. Превод Милене Владић Јованов.
} 
у коментару уз „Пусту земљу” већ је то и сам Елиот као аутор песме. Међутим, сам глас Елиот предаје Филомели и у томе се опет може видети тема чулности која једина сама може да изрази сопствено искуство, али опет и метаквалитет јер песник спаја ову слику и даје назнаке да је он то учинио. Филомела проговора ко ју је силовао али начином птичијег језика, крештавим гласом ластавице. Међутим, појављује се и нешто што је необично. На језичком плану нема само ономатопејских звукова, већ и једно материјално, означено Тереу, које упућује да је реч о Тереју као њеном силоватељу а чије име је требало у миту да буде скривено, због чега је Филомели и одсечен језик да о томе не би проговорила. Дакле античка, „вечна” прича, или културолошки вечна, спојила се са савременом, у облику чулног изражавања које је увело и теоријске квалитете у самој модернистичкој поетици као што је аутореференцијалност и метаквалитет.

Закључићемо да је Елиот такође писао о светом, о религиозном, у раној поезији, које се преточило касније у различите облике религија које се појављују у „Квартетима”, од хришћанске, будистичке до хинду мисли. У раној поезији позната је песма састављена од четрнаест песама, колико је било и станица на Христовом путу до Голготе названом Via Dolorosa. Под тим називом Елиот пише песму састављену из више делова. Међутим, у њима се налазе песме у којима се изразито поставља питање интроспекције и самоиспитивања, од појавности и сагледавања појавности до мишљења које није једноставно обликовати. У њима се и први пут јавља фигура чувеног духа пратиоца коме се песнички субјекат обраћа са својим сазнањима, а који ће касније у „Квартетима” прерасти у познату „сложену авет”. Међутим, света земља није уметност за Елиота, као што је за Јејтса, већ је за Елиота уметност та која у себи упија све могуће елементе из културе и представља највиши могући облик људског изражавања уопште. За Елиота је најважнији облик у датом изражавању био преображај и више га је занимала смена чулног и вечног у стварању идентитета, док је дата смена Јејтса занимала више у области уметности коју је, како смо већ навели, сматрао светом. Преображај најбоље у уметничком изразу и стварању песничке слике можемо уочити у интертекстуалном простору који се отвара између факсимила „Пусте земље” у коме се види рад Паундове критичарске руке, и самог поетског текста који је Елиот објавио. Међутим, види се и оно што проницљивом читаоцу не може да промакне, а то је да је Елиот неке од песама које је Паунд у потпуности избацио из „Пусте земље”, оставио у самом тексту у облику стихова трагова. Касније у још једном интертекстуалном окрету, може се уочити да је Елиот Паундову „исправку” исправио јер је песму о којој говоримо а то је „Смрт св. Нарциса” касније објавио у збирци песама под насловом „Песме писане у раној младости”. ${ }^{37}$ Дакле, поетски систем је

${ }^{37}$ Видети: Т. S. Eliot: Poems Written in Early Youth, New York, Farrar, Straus and Giroux, 1967. 
сложен, а у њему у стварању истог, са темом конструисања и самоспознаје идентитета, највише је одиграла улогу филозофско-деконструкционистичка категорија понављања која у овој песми има одисејску структуру. Наиме, почетак песме упућује на њен крај. Крај уочавамо у почетним стиховима. Поред тога, преображај уочавамо у самом поетском субјекту Нарциса, али и у поновљеним стиховима у „Пустој земљи” који припадају песми о Нарцису.

Погледајмо како дата песма изгледа у факсимилу.

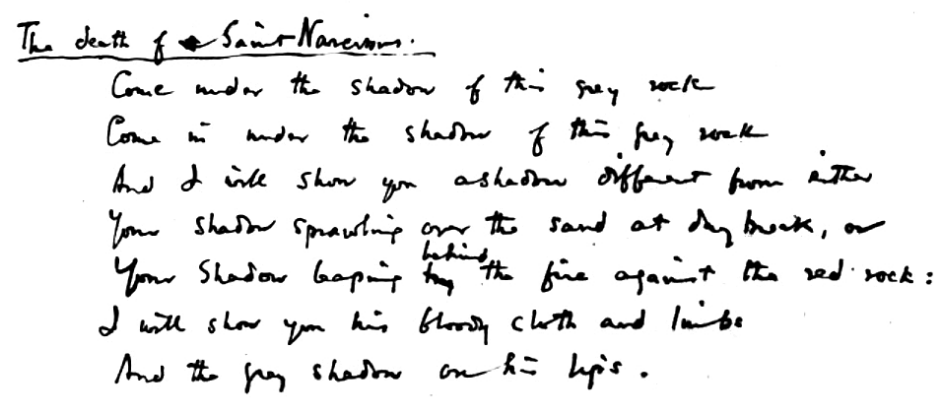

He watkes once brean the wa and the hift cliffs

Whare the lind made $h=$ avare of $l=$ lags inoottel possming each.thor

Ans of his ame cascess ove his theest.

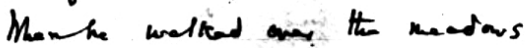

the was stifes and soothat by his oum rytter.

by the nive

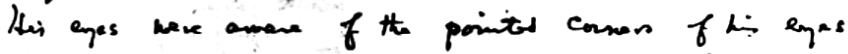

Ano $k i$ hands amane of the taps of $h=$ fingess.

Struek down ks sued knowledige

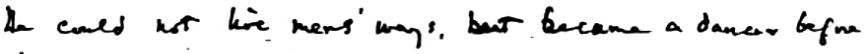

of teralked in cith sthets

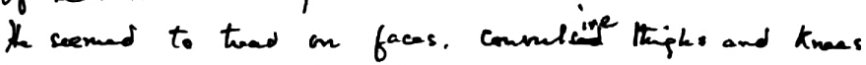

So he care out to live under thorek.

P.T.L 




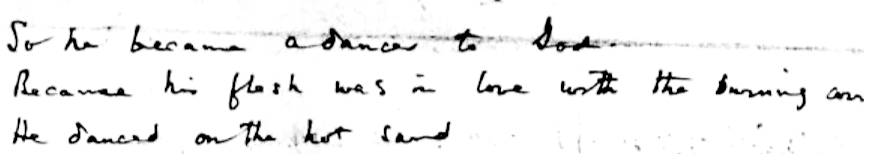

Until the arrows came.

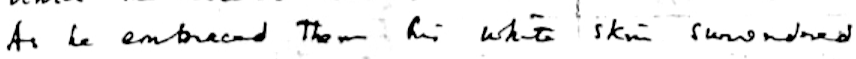

itieg to the retioss of blows, and satifies kin

row be is quean, on and stamed

list the shasor mi $k=$ monte.

У преводу, то би звучало овако:

Смрт св. Нарциса

(песникова прича упозорења)

Дођи под сенку ове сиве стене -

Уђи под сенку ове сиве стене,

И показаћу ти нешто потпуно другачије

Твоју сенку како се прући преко песка

У праскозорје, или

Твоју сенку што у одразу ватре игра

На црвеној стени:

Показаћу ти његове окрвављене хаљине 
И удове

И сивкасту сенку на његовим уснама.

Једном давно корачао је стазом

Између мора и литица

Кад је на ветру осећао своје удове како се крећу

Прекрштених руку на грудима.

Док је корачао преко ливада

Умирен властитим ритмом

Поред реке

Постаде свестан оштрих углова својих очију

И испружених врхова прстију.

\section{Погођен тим сазнањем}

Одбаци људски живот, и постаде играч пред Богом

Када је ходао улицама града

Као да је газио преко лица, згрчених бутина и колена

И изађе тако испод стене.

Најпре је мислио да је био дрво,

Испреплетених грана

Замршеног корења.

Онда је знао да је био риба

Склиског беличастог стомака чврсто стегнутог његовим прстима, Која се копрца у његовом стиску руке, чију древну лепоту

Чврсто држе ружичасти врхови прстију нове лепоте.

Онда је био девојчица

Коју је у шуми ухватио пијани старац,

Спознајући на крају укус његове белине,

Ужас глатке коже,

И његов пијани задах и старост.

На крају постаде играч Богу.

Јер је његово тело жудело за пламтећим стрелама

Играо је на врелом песку

Све док се стреле нису зариле

У беличасту кожу која их пригрли

И предаде се црвенилу крви 
И он би задовољан.

Сада је зелен, сув, обележен

Са сенком у устима. ${ }^{38}$

Нарцис је, да прича буде још сложенија, практично лик из историје. Наиме, реч је о свештенику. Тако се и овде отвара пут ка спољашњости, ка историјском, али се истовремено отвара и пут ка самом делу које је поновљено и у коме Нарцис има две рефенцијалности: ону спољашњу из историје и ову унутрашњу из саме песме и „Пусте земље”. Као што се из превода може уочити, Нарцис почиње стиховима са крвавим хаљинама где дати поетски субјекат завршава. Без обзира на његов преображај и мењање ликова у самој песми, за стварање идентитета најважнији је преображај који се догађа у простору између „Пусте земље” и песме о Нарцису. Ту се наравно отвара интертекстуални простор који нас води до истовеменог постављања Нарциса кога познајемо из Овидијевих „Метаморфоза”, наведених као једно од најзначајнијих дела на које се Елиот ослањао у писању „Пусте земље”, и лика Нарциса који се јавља у Елиотовим песмама. Оно што је основно у његовом идентитету јесте прихватање одсуства као промене и разлике, одсуства као представе смрти, да би живот и присуство функционисали. Слично ономе што је Јејтс написао у чувеним стиховима да је смрт у животу и живот у смрти, које смо горе у тексту цитирали. Дублетна поетика јесте оно што је одлика Јејтсовог стваралаштва, али се итекако може закључити да су и ова два песника стварала међусобно у својим песмама критичке ставове и оснаживала идеју дублетности у уметничком стварању. Такође би занимљиво било за који тренутак осмотрити и критички моменат као и рад читаоца у стварању, односно писању песме који му управо омогућава дублетна поетика. Навели смо пример читаочевог рада у,„склапању” песме из Елиотове „Прве расправе о души и телу”, а сада ћемо то учинити са дублетним песмама Јејтса, „Путовање у Визант” и „Визант”. Читаочева песма би изгледала управо као кључ и енкодирање песничког кода између две песме. Односи се на преплет чулног и вечног, смртног и бесмртног, али и на стварање уметничког дела управо у преплету ових категорија. Читаочева песма у том смислу би изледала овако:

Читалац, на делу, открива скривено и ствара ново:

Ту друге школе певања нема, све је тек

Изучавање сопствене величине. („Путовање у Визант”)

Спалите ми срце, болно од жеље, што га

${ }^{38}$ T. S. Eliot: The Waste Land, A Fascimile and Transcript of the original Drafts Including the Annotations of Ezra Pound, нав. дело, стр. 95-97. Превод Милене Владић Јованов. 
Милена Владић Јованов, Интертекстуални дијалог између песама: Јејтсове ...

Сво̀је и звер што цркава,

Јер оно не зна шта је; кости ове

Скупите у том чуду што се вечност зове. („Путовање у Визант”)

Кад одем из природе, облик тварни

Никада више нећу припозвати,

Већ онај што га грчки ковинари

Творе у емајлу, лију у позлати,

На златној грани ћу запевати

За византску господу и госпође

О оном што би, бива, ил ће да дође. („Путовање у Визант”)

Купола месечаста, звездоока,

Презире све што јесмо,

То пуко замешатељство,

Помаму и глиб крвотока. („Визант”)

На златној грани, под звездом што светли

Може да пева ко у Хаду петли,

Ил бесно због месеца да се острви

У слави метала вазда истог,

Латице, обичне птице, и свег тог

Замешатељства од глиба и крви. („Визант”)

Дуси рођени из крви се јате

Одбацују замешатељство, муку,

Стиже дух за духом; а силину вала

Зауставља златна ковачница Цара!

Мермерна, плесна дворана зачара

Замешатељство са клетвом многом,

Те слике које

Двоје се и троје. („Визант”)

Завршавамо са песмом како смо и почели. Читалац је у дублетној поетици изразито укључен. Не смемо заборавити да је он семиотички читалац, који прати аутора, али се увек у својим читањима мора вратити и семантичким нивоима у свом читању јер се може преварити у својим путевима читања и писања. Процес читаочевог учешћа је стога веома активан, као што су динамичне и дублетне поетике, како Јејтсова, тако и Елиотова, а и њихов међусобни однос. Погледајмо не само како се у овој песми преплићу чулно и вечно, већ и како се преображава песничко искуство и шта све значи уметничко дело, како онима који су поетски субјекти у песми тако и симболично свима онима који ће вечну, универзалну песму читати и слушати. 


\section{ЛИТЕРАТУРА}

Abot, H. Porter, Uvod u teoriju proze, prevela Milena Vladić, Beograd, Službeni glasnik, 2009.

Austin, William James, A Deconstruction of T. S. Eliot, The Fire and The Rose, New York, The Edwin Mellen Press, 1996.

Bush, Roland, T. S. Eliot, A Study in Character and Style, Oxford, Oxford University Press, 1983.

Vladić Jovanov, Milena, Dinamični poetski sistem T. S. Eliota, Beograd, Službeni glasnik, 2014.

Genette, Gerard, Palimpsests, Translated by Channa Newman and Claude Doubinsky, Lincoln and London, University of Nebraska Press, 1997.

Eliot, Thomas Stearns, The Complete Poems and Plays 1909-1950, New York, Harcourt Brace and Company, 1952.

Eliot, Thomas Stearns, Poems Written in Early Youth, New York, Farrar, Straus and Giroux, 1967.

Eliot, Thomas Stearns, The Waste Land, A Fascimile and Transcript of the Original Drafts Including the Annotations of Ezra Pound, New York, A Harvest Book, Harcourt, INC., 1971.

Eliot, Thomas Stearns, Inventions of the March Hare, Poems 1909-1917, New York, Harcourt Brace and Company, 1996.

Елиот, Томас Стернс: Песме, приредио Јован Христић, Београд, Српска књижевна задруга, 1998.

Eco, Umberto, On Literature, Translated from the Italian by Martin McLaughlin, New York, Harcourt, INC., 2003.

Eco, Umberto, The Role of the Reader, Explorations in the Semiotics of Texts, Bloomington, Indiana University Press, 1984.

Јејтс, Виљем Батлер, Ја сам из земље Ирске, изабрао и препевао са енглеског Милован Данојлић, Београд, Удружење издавача и књижара Југославије, 1999.

Calinescu, Matei: Five Faces of Modernity, Modernism, Avant-Garde, Decadence, Kitch, Postmodernism, Durham, Duke Univesity Press, 1987.

The Cambridge Companion to Modernism, edited by Michael Levenson, Cambridge, Cambridge University Press, 2003.

The Cambridge Companion to W. B. Yeats, edited by Marjorie Howes and John Kelly, Cambridge, Cambridge University Press, 2006.

The Cambridge Companion to T. S. Eliot, edited by A. David Moody, Cambridge, Cambridge University Press, 1994.

The Cambridge Companion to Ezra Pound, edited by Ira B. Nadel, Cambridge, Cambridge University Press, 1999. 
Longenbach, James, Stone Cottage, Pound, Yeats, and Modernism, Oxford, Oxford University Press, 1988.

Martin, Volas, Novije teorije pripovedanja, prevela Milena Vladić Jovanov, Beograd, Službeni glasnik, 2016.

Menand, Louis, Discovering Modernism, T. S. Eliot and His Context, Oxford, Oxford Univesity Press, 2007.

Marcus, Phillip L., Yeats and Artistic Power, New York, Syracuse University Press, 2001.

Orr, Marry, Intertextuality, Debates and Contexts, Cambridge, Polity Press, 2003.

Паунд, Езра, Песме, избор, превод, предговор и коментари Милована Данојлића, Београд, Београдски издавачки-графички завод, 1975.

Poirier, Richard, Poetry and Pragmatism, Cambridge, MA, Harvard Univeristy Press, 1992.

Свето писмо, Корићанима посланица прва св. апостола Павла, превео Вук С. Караџић, Београд, Југословенско библијско друштво, 2003.

Silverman, Hugh James: Textualities, Between Hermeneutics and Deconstuction, New York and London, Routledge, 1994.

Yeats, William Butler, The Collected Poems of W. B. Yeats, New York, Scribner Paperback Poetry, 1989.

Milena Vladić Jovanov

\section{INTERTEXTUAL DIALOG ZWISCHEN W. B. YEATS GEDICHTEN ZWIEGESPRÄCH ZWISCHEN SELBST UND SEELE UND T. S. ELIOTS ERSTE UND ZWEITE DEBATE ZWISCHEN KÖRPER UND SEELE}

(Zusammenfassung)

Der Beitrag präsentiert einen intertextuellen Ansatz beim Studium zweier Gedichte von W. B. Yeats und T. S. Eliot. Bei der Analyse der Gedichte wurde jedoch die Poetik jedes Dichters separat dargestellt. In diesem Zusammenhang wird der Begriff der Dublett Poetik vorgestellt, der ein besonderheit in Yeats Werken, aber auch in gewissen Nuancen Eliot's poetisches System kennzeichnet. Die Doublett Poetik zeigt ein wichtiges Merkmal der modernistischen Poetik. Es geht um Selbstreferenzialität, bei der die Realität und Referenzialität eines Gedichtes in seinem Dublett liegt und nicht in der Realität welches objektiv oder subjektiv verstanden wird. Die gleichzeitige Verdrehung der Gedichte zu sich selbst stellt die Verdrehung des Äußeren und die Darstellung der den Künstler umgebenden Realität dar und zeigt damit insbesondere seine gesellschaftliche Rolle. Er schreibt nicht mehr von den Ereignissen des Tages und seiner Zeit, sondern schreibt von der Realität, die er durch frühere Kunstwerke oder durch die Wiederholung seiner eigenen sieht, in deren intertextuellen Raum sich die kritische Meinung des Lesers formt. Der Leser ist aktiv und durchläuft sowohl die semiotische als auch die semantische Phase in der poetisch-strukturell-semantischen Verflechtung. Die Frage nach der Meta-Qualität eröffnet sich auch deshalb, weil der Dichter den Weg seiner eigenen Schöpfung zeigt, indem er über seine Schöpfungserfahrung schreibt. Modernistische Meta-Qualität ist komplex. Wir sehen den Dichter nicht direkt wie in der Postmoderne, sondern durch die Erfahrung der Schöpfung 
beschreibt und zeigt den Weg der Schöpfung und er öffnet sein Werk für die dynamische Beteiligung des Lesers. Gleichzeitig eröffnet die poetische Erfahrung kritisch durchdachte binäre Gegensätze, die hinterfragt werden und die die gesamte menschliche Kultur hierarchisch und ideologisch beherrscht haben. Die Dichter überdenken das Verhältnis von Sinnlichem und Ewigem, Tod und Leben, Gegenwärtigem und Abwesendem, Äußerem und Innerem und kommen zu dem Schluss, dass es immer um die Verflechtung vorgegebener Begriffe geht und nicht um deren ausschließliche Wahl.

Schlüsselwörter: Dublett Poetik, Selbstreferenzialität, Meta-Qualität, poetische Erfahrung, strukturell-semantische Beziehungen, semiotischer und semantischer Leser, binäre Oppositionen, poetisches System.

Примљено 4. јуна 2021, прихваћено за објављивање 29. јуна 2021. године. 